\title{
The Common Law Sovereignty of Religious Lawfinders and the Free Exercise Clause
}

\author{
Bernard Roberts
}

The ascending theme of contemporary free exercise jurisprudence is that the Free Exercise Clause of the First Amendment ${ }^{1}$ imposes no presumptive structural limitations upon the state's authority to regulate religious activity. This theme resounds throughout the opinion of the U.S. Supreme Court in Employment Division, Department of Human Resources $v$. Smith, ${ }^{2}$ which held that the state may, without showing a specific compelling state interest, prohibit a person from performing actions that he is religiously obliged to perform.

As a matter of words, one might question the Court's holding and wonder if there is a construction of the Clause more consistent with constitutional precedent and principle. ${ }^{3}$ As a matter of history, one might attempt to revisit the religious culture that shaped the time of framing and ratification of the Constitution and observe that contemporary construction is out of touch with that history. ${ }^{4}$ Yet, between the overarching method of history and the legaltechnical method of construction there lies a middle way: step outside of constitutional law, but not outside of law. Then listen to how this ascending theme resonates with the law's understanding of the relationship between civil and religious authority, and with the law's self-understanding.

This Note shall go the middle way. I hope to demonstrate that the principle at work in Smith, which animates contemporary free exercise jurisprudence, is deeply at odds with a doctrine of American common law that binds civil courts to the holdings of religious lawfinders in those civil cases that implicate religious law. ${ }^{5}$

1. U.S. CONST. amend. I ("Congress shall make no law . . . prohibiting the free exercise [of religion]."). The Supreme Court declared the Free Exercise Clause applicable to the governments of the several states in Cantwell v. Connecticut, 310 U.S. 296, 303 (1940).

2. 110 S. Ct. 1595 (1990).

3. See Michael W. McConnell, Free Exercise Revisionism and the Smith Decision, 57 U. CHI. L. REV. 1109 (1990). But see William P. Marshall, In Defense of Smith and Free Exercise Revisionism, 58 U. CHI. L. REV. 308 (1991).

4. See Mark DeWolfe Howe, The Garden AND tHe WILDERNess 1-31 (1965); John T. NoONAN, THE BELIEVER AND THE POWERS THAT ARE (1987).

5. I shall use the term "religious lawfinder" to describe that body in a religious community which expounds the religious law of that community. Religious lawfinders may occupy a formal or an informal role in the religious community, depending upon how the community is ordered. Some formal examples include church judicatories, presbyteries, Catholic canon law courts, and the Jewish Beth Din. Questions 
There are two reasons why such a demonstration should be of interest for the constitutional lawyer as well as for the legal observer concerned with religious liberty. First, this common law doctrine and its animating logic allow us a glimpse of how the common law understands the nature of the legal relationship between civil and religious authority. The doctrine may also convey the law's understanding of its own structure and of the limits of the state under a system of constitutionalism. These understandings, because they go to the structure of the system of law itself, might inform a contemporary lawyer's evaluation of current constitutional jurisprudence.

The second reason for exploring this tension between classical common law and contemporary constitutional construction is predicated upon a particular model of constitutional interpretation: one way of understanding the Constitution is to read it as a law that draws meaning from the context of surrounding law and tradition. ${ }^{6}$ The framing of the Constitution, as well as the ensuing events of its construction, took place within a culture dominated both by the legal terminology, methods, and habits of the common law, and by a certain set of historic traditions respecting the nature of religious organizations. ${ }^{7}$ Thus, any attempt to interpret the Constitution should seek some guidance from common law and tradition. At the least, we should be wary of those constitutional interpretations that ignore or defy the interpretive resources of the common law and the accompanying social and historic traditions.

Part I of this Note will consider contemporary free exercise doctrine with an eye toward distilling the basic conception of sovereignty implicit in that modern doctrine. Part II will explore the common law doctrine of legal sovereignty for religious lawfinders, with special attention to the history and the inner logic of that doctrine. Part III will attempt an analysis of this doctrine and suggest a "religious question doctrine," that tracks the structure of the political question doctrine as a device for evaluating the nature and limits of the state's lawfinding authority. Part IV of the Note will offer some speculations about the analytical and legal soundness of contemporary free exercise doctrine.

of religious law that may implicate secular rights include: Which of two parties to a schism has remained loyal to the church's essential doctrine, and which has diverged? See Watson v. Jones, 80 U.S. (13 Wall.) 679 (1871). Does a certain merchant's method of preparing food qualify as kosher? See S.S. \& B. Live Poultry Corp. v. Kashruth Ass'n, 158 Misc. 358 (N.Y. Sup. Ct. 1936).

6. The use of tradition as a canon of constitutional interpretation has been embraced by some members of the Court, including Justices Rehnquist, Scalia, and Kennedy, all of whom were in the majority in Smith. In Michael H. v. Gerald D., 49 I U.S. 110 (1989) (suit to determine paternity), the Court held, in an opinion written by Justice Scalia, that the Due Process Clause of the Fourteenth Amendment draws meaning from the interests "traditionally protected by our society," id. at 122, and that the Court's construction of the meaning of the liberty interest protected by the Due Process Clause should be informed by "the historic respect-indeed, sanctity would not be too strong a term - traditionally accorded to the relationships that develop within the unitary family." Id. at 123.

7. For an extremely thorough examination of the traditions regarding religious societies in America, see Michael W. McConnell, The Origins and Historical Understanding of Free Exercise of Religion, 103 HARV. L. REV. 1409 (1990). 


\section{SOVEREIGNTY AND CONTEMPORARY FREE EXERCISE DOCTRINE}

There has lately come a surge of judicial interest in the arduous task of toying with the tangle of our free exercise doctrine. In the past several years, courts have frequently addressed the constitutional limitation on the authority of the state to regulate religious liberty. ${ }^{8}$ The decision of the Supreme Court in Employment Division, Department of Human Resources v. Smith represents a crucial step in this developing doctrine of the Free Exercise Clause. ${ }^{9}$

In this part of the Note, I will briefly examine the Court's decision in Smith and try to distill the central principle of that case regarding the relationship between civil and religious authority. I will then juxtapose the Smith principle with the antecedent constitutional tradition.

\section{A. The Rule in Smith}

Alfred Smith was a member of the Native American Church, which has as its central practice the sacramental use of peyote, a growth that occurs naturally in cactus plants. ${ }^{10}$ Sacramental usage includes both reverence and ingestion of the peyote. People who embrace the peyote religion believe that peyote embodies the Holy Spirit and, as such, is itself the object of profound reverence. Believers hold that the solemn ingestion of peyote at religious ceremonies allows for an intimate communion between themselves and their maker. ${ }^{11}$ Such sacramental usage of peyote, first recorded by Spanish historical sources in 1560 , is very likely an ancient practice that has defined much of Native American religious culture for several centuries. ${ }^{12}$

In 1977 the legislature of Oregon classified peyote, which produces hallucinogenic effects upon ingestion, as a "controlled substance," the possession of which constituted a Class B felony punishable by a maximum of ten years imprisonment. ${ }^{13}$

8. See, e.g., Hernandez v. Commissioner, 490 U.S. 680 (1989) (no charitable deduction for payments made by member to Church of Scientology); Frazee v. Hllinois Dep't. of Employment Sec., 489 U.S. 829 (1989) (denial of unemployment benefits to Christian who refuses to work on Sunday prohibited by First Amendment); Texas Monthly, Inc. v. Bullock, 489 U.S. 1 (1989) (voiding statute exempting religious publications from sales tax); Lyng v. Northwest Indian Cemetery Protective Ass'n., 485 U.S. 439 (1988) (government may harvest timber on sacred Indian ground); O'Lone v. Estate of Shabazz, 482 U.S. 342 (1987) (Muslim prison inmate has no right to attend religious services); Bowen v. Roy, 476 U.S. 693 (1986) (citizen must have social security number despite religious qualms); Goldman v. Weinberger, 475 U.S. 503 (1986) (Orthodox Jew in Air Force has no right to wear yarmulke); Thornton v. Caldor, Inc., 472 U.S. 703 (1985) (statute giving believers the right not to work on their Sabbath violates Establishment Clause); United States v. Lee, 455 U.S. 252 (1982) (Amish must pay employment social security tax).

9. 110 S. Ct. 1595 (1990).

10. For a particularly trenchant discussion of the role of peyote in the Native American Church, see People v. Woody, 394 P.2d 813 (Cal. 1964).

11. This belief has a close analog in the Catholic tradition, which holds that the transubstantiated bread and wine are the actual body and blood of Jesus Christ. 5 CATHOLIC ENCYCLOPEDIA 572-73 (1909).

12. See EDWARD F. ANDERSON, PEYOTE: THE DIVINE CACTUS 3 (1980).

13. OR. REV. STAT. §§ 161.605(2), 475.992(4) (1987). 
The issue in Smith was whether the Free Exercise Clause required the state to either carve out a "religious use" exception in the application of the criminal statute or to demonstrate a compelling state interest as to why it could not make such an exception.

The Supreme Court, in an opinion written by Justice Scalia, limited its holding in Smith to instances of legislation designed to regulate some other social phenomenon, but having incidental or unintended effects upon a person's free exercise of religion. ${ }^{14}$ The case at hand involved a statute that targeted the abuse of drugs, and the Court likened it to a statute enforcing the collection of taxes; both are generally applicable statutes that may have the effect of inhibiting the free exercise of religion. ${ }^{15}$ The Court found that such incidental inhibition of religious practice was of no constitutional moment and therefore held that the state has presumptive constitutional authority to regulate a person's religious behavior without having to demonstrate a compelling state interest. ${ }^{16}$ Thus, Smith established the proposition that the state may always prohibit a religiously required action, so long as that prohibition is indirect. ${ }^{17}$

\section{B. The Sherbert Line and the Presumption of Sovereignty}

Smith is an important case because it shifts presumption. An intricate legal dynamic flows between civil and religious authority. Religiously devout persons pledge their allegiance simultaneously to both systems as those systems operate

14. Smith, $110 \mathrm{~S}$. Ct. at 1599-1600.

15. A statute enforcing the collection of taxes might also inhibit some other constitutionally privileged activity. Justice Scalia used the example of freedom of the press. Id.

16. Id. at 1603-04.

17. Lower courts have recognized Smith as a substantial alteration of free exercise doctrine and are citing it as precedent for rejecting the free exercise claims of litigants, including many cases beyond the ambit of criminal law. See Peyote Way Church of God v. Thornburgh, 922 F.2d 1210, 1213 (5th Cir. 1991) (upholding Texas law criminalizing peyote: "[T]he Supreme Court's decision in Smith eviscerates judicial scrutiny of generally applicable criminal statutes in response to free exercise challenges." (citation omitted)); Roberts v. Madigan, 921 F.2d 1047, 1059 (10th Cir. 1991) (holding Free Exercise Clause gives no right to student to read Bible silently during his study period at public school); Salvation Army v. New Jersey Dep't of Community Affairs, 919 F.2d 183, 185 (3d Cir. 1990) (Salvation Army allowed exemption from New Jersey rooming and boarding statute); Saint Bartholomew's Church v. City of N.Y., 914 F.2d 348, 354 (2d Cir. 1990) (church prohibited from making liturgically significant alterations in church building); United States v. Board of Educ., 911 F.2d 882, 888 (3d Cir. 1990) (Muslim schoolteacher prohibited from wearing religiously required headscarf); South Ridge Baptist Church v. Industrial Comm'n of Ohio, 911 F.2d 1203, 1213 (6th Cir. 1990) (Boggs, J., concurring) (church not exempt from mandatory worker's compensation scheme: "Since the Supreme Court [after Smith] now appears to have confined the applicability of ... [the compelling-state-interest test] to the rather limited field of unemployment compensation, I must reluctantly concur in the court's opinion."); Intercommunity Ctr. for Justice and Peace v. INS, 910 F.2d 42, 44 (2nd Cir. 1990) (Catholic organization must verify immigration status of its workers); Salaam v. Lockhart, 905 F.2d 1168, 1171 (8th Cir. 1990) (Muslim prisoner has no right to change his name: "Smith . . . brings the free exercise rights of private citizens closer to those of prisoners."); United States $v$. Philadelphia Yearly Meeting of Religious Soc'ys, 753 F. Supp. 1300, 1302 (E.D. Pa. 1990) (Free Exercise Clause gives Quakers no exemption from taxes supporting military); Yang v. Sturner, 750 F. Supp. 558, 558 (D.R.I. 1990) (court recalling its own decision to award damages to Hmong parents for performance of religiously prohibited autopsy on their son: "It is with deep regret that I have determined that [Smith] mandates that I recall my prior opinion."). 
within their appropriate spheres of governance. The rule in Smith comes upon this delicate balance and shifts the presumption of ultimate legal sovereignty ${ }^{18}$ squarely to the state. ${ }^{19}$ Thus, the animating principle of Smith is that the state is presumed to be legally authorized to regulate religious freedom. Such presumption has lately become settled law when the injured party is an inmate at a prison ${ }^{20}$ or an officer at a military base. ${ }^{21}$ But presuming the state has legal sovereignty over the religious actions of ordinary citizens in a free society is a remarkable development in our free exercise doctrine.

The importance of this shift of presumption comes into focus when we consider the law from which Smith diverged: the line of cases beginning with Sherbert $v$. Verner. ${ }^{22}$ Sherbert, a case that awarded unemployment compensation to a Seventh Day Adventist who was fired because she refused to work on Saturdays, crafted a two part analysis for adjudicating the constitutionality of statutes that infringe upon religious liberty. First, the court asks whether the statute imposes any burden upon the person's free exercise of religion. If the court finds such a burden it moves to the second step, asking whether the state has demonstrated a compelling state interest that justifies burdening religious liberty. ${ }^{23}$

A close look at the Sherbert analysis reveals an understanding of sovereignty that is distant from that of Smith. A statute that interferes with the free exercise of religion is immediately presumed unconstitutional. The state may then, through a separate analysis, overcome this presumption by demonstrating that some compelling state interest justifies the interference. ${ }^{24}$ The sphere of

18. I use "legal sovereignty" to distinguish the operative concept in this Note from "political sovereignty." For a regime to possess legal sovereignty it must, as a matter of right, exercise authority over all within that regime, with none possessing the capacity to override it. For a regime to possess political sovereignty it is enough that its will simply prevail over the will of any competitor. See Stanley I. Benn, Sovereignty, in 7 ENCYCLOPEDIA OF PHILOSOPHY 501-05 (Paul Edwards ed., 1967). The appearance of the word "sovereignty" in this Note shall mean "legal sovereignty."

19. Of course, the shift in presumption was not necessary in order to uphold Oregon's drug statute. Justice $O^{\prime}$ Connor would have utilized the compelling-state-interest test and held that Oregon possessed a compelling state interest to affect religious liberty in this case. Smith, $110 \mathrm{~S}$. Ct. at 1606-15 (O'Connor, J., concurring).

20. O'Lone v. Estate of Shabazz, 482 U.S. 342 (1987) (prison may refuse to allow inmates to attend worship services).

21. Goldman v. Weinberger, 475 U.S. 503 (1986) (military may prohibit wearing of yarmulkes).

22. 374 U.S. 398 (1963).

23. The rule in Sherbert was followed in Frazee v. Illinois Department of Employment Security, 109 S. Ct. 1514 (1989) (awarding unemployment benefits to person who refused to work on Sunday for religious reasons but was not member of any organized religion); Hobbie v. Unemployment Appeals Commission, 480 U.S. 136 (1987) (holding denial of unemployment compensation to Seventh Day Adventist who came to her religious beliefs after holding job for some years and was terminated for requesting change in schedule violates Free Exercise Clause); Thomas v. Review Board, 450 U.S. 707 (1981) (holding termination of unemployment compensation for Jehovah's Witness who quit job because his religion forbade participation in production of armaments violates Free Exercise Clause).

24. For inquiries into the method of this separate analysis, see Richard A. Posner \& Michael W. McConnell, An Economic Approach to Issues of Religions Freedom, 56 U. CHI. L. REV. 1 (1989), and the articles cited there. The two analyses at work are structural (what sorts of things can a thing like $X$ do?) and existential (what do we do right now?). The specific needs of governance exceed constitutional providence and so authority is justly conferred by both structure and circumstance. The important point is 
religious liberty is thus staked out, and the state may not enter without justification.

Sherbert recognized that the Free Exercise Clause does not absolutely prohibit the state from regulating any religious conduct. The logic at work in the Sherbert analysis is consistent with the following theory of the Free Exercise Clause: The federal government, as called into being by the Constitution of the United States, is designed with several inherent limitations; inter alia, it is unauthorized to regulate religious liberty. ${ }^{25}$ But this limitation, while presumptively binding, is not absolute. The presumption of constitutional incapacity can be overcome only if the state can prove, through a separate analysis, a compelling interest that justifies an extraordinary exercise of state power. ${ }^{26}$ Sherbert thus described the Free Exercise Clause as a presumptive structural limitation on the ambit of legitimate state authority, placing the burden of proof upon the state to show that it is authorized to exercise power in the specific case.

Smith held that Sherbert does not apply to generally applicable criminal statutes, but only to the unemployment compensation field, ${ }^{27}$ a field that especially lends itself to ad hoc evaluations of claims in a way that criminal prohibitions do not. It is unclear from the opinion why the Constitution compels religious exemptions in the context of administrative law, but not criminal law. Such a distinction contains the curious implication that constitutional requirements are conceptually subsequent to the statutory mechanics that facilitate their fulfillment. ${ }^{28}$

More apparent in the opinion is the visceral notion that carving out religious exemptions to criminal laws denigrates the sovereignty of the state by allowing each person "to become a law unto himself." ${ }^{29}$ Such splintering of legal sover-

that before Smith, structural limitation on authority was privileged over existential grants of authority in the realm of religious liberty.

25. This deficiency was then imposed, ex post, upon the governments of the states via the Fourteenth Amendment. Supra note 1.

26. Justice Jackson's opinion for the Court in West Virginia Board of Education v. Barnette, 319 U.S. 624 (1943), presages the Sherbert analysis:

The right of a State to regulate, for example, a public utility may well include . . . power to impose all of the restrictions which a legislature may have a "rational basis" for adopting. But freedoms of speech and of press, of assembly, and of worship may not be infringed on such slender grounds. They are susceptible of restriction only to prevent grave and immediate danger to interests which the State may lawfully protect.

Id. at 639 .

27. Employment Div. v. Smith, 110 S. Ct. 1595, 1602-03 (1990).

28. The Court specifically refused to undertake a compelling state interest analysis because such an analysis would threaten to carve out "a private right to ignore generally applicable laws . . . [which would constitute] a constitutional anomaly." Id. at 1604 . The Court does not explain why a "private right" to a religious exemption in a generally applicable unemployment compensation statute is less anomalous than a religious exemption in a generally applicable criminal statute.

29. Id. at 1603 (quoting Reynolds v. United States, 98 U.S. 145, 167 (1878) (applying law criminalizing polygamy to Mormons despite claim that polygamy is required by Mormon religion)). Smith's reliance upon Reynolds may be misplaced. Reynolds employed a crude version of the compelling-state-interest analysis by opining that the government's interest in monogamy justifies prohibition of polygamy. Reynolds, 98 U.S. at 165-66. There is a much greater structural similarity between Smith and another Mormon case, Late 
eignty, according to Smith, "contradicts both constitutional tradition and common sense." 30

Here the Court has laid out the central puzzle of this Note: Does a model of splintered legal sovereignty contradict either constitutional tradition or common sense? Or, on the contrary, does such a model, which we might rename "legal pluralism," 31 embody a fundamental instinct of American common law that has shaped the foundation of American constitutional law?

\section{THE COMMON LAW Doctrine OF RELigious Legal SOVEREIGNTY}

A doctrine of American common law, which received its classical formulation in Watson v. Jones, ${ }^{32}$ directs civil courts to follow the holdings of religious lawfinders in certain circumstances. In this part of the Note, I will establish the classic formulation of the doctrine. I will then inquire into the inner logic of the doctrine by investigating its common law origins and the structure of its legal reasoning.

\section{A. The Watson Doctrine}

The American Civil War set sister against sister and brother against brother in religious communities as well as in families. In Louisville, Kentucky, one chapter of the Presbyterian Church divided between the proponents of slavery and the abolitionists. Each side claimed it was the legitimate representative of the Presbyterian Church, and each side laid legal claim to the church building and grounds. The American Presbyterian Church was centrally organized with a national judicatory (i.e., lawfinding body) located in the General Assembly. ${ }^{33}$ The power of "deciding in all controversies respecting doctrine and discipline; ... [and] of suppressing schismatical contentions and disputations," was reserved for the General Assembly, sitting as judicatory. ${ }^{34}$ In 1866 the General

Corporation of the Church of Jesus Christ of Latter Day Saints v. United States, 136 U.S. 1 (1890). In 1887 Congress dissolved the corporation of the Mormon Church and seized all of its property. In a remarkable opinion, the U.S. Supreme Court found this disestablishment of religion to be part of Congress' "plenary" power over the Territory of Utah, despite the First Amendment. Id. at 42. This reasoning, as in Smith, locates the presumption of authority in the actions of the state, even when those actions invade areas specifically protected by the Bill of Rights. Oddly, the Court in Smith makes no mention of Latter Day Saints. See generally LEONARD J. ARRINGTON \& DAVIS BITTON, THE MORMON EXPERIENCE (1979).

30. Smith, $110 \mathrm{~S}$. Ct. at 1603.

31. See generally Perry Dane, The Maps of Sovereignty: A Meditation, 12 CARdozo L. Rev. 959 (1991). Robert Cover, Nomos and Narrative, 97 HARV. L. REV. 4 (1983); OTTO GIERKE, POLITICAL THEORIES OF THE MIDDLE AGE (Frederic M. Maitland trans., 1900). Legal pluralism proceeds from the observation that the state does not exhaust the social experience. This Note is concerned with legal pluralism to the extent that it observes that the state's civil courts are not the ultimate lawfinders in some areas of law.

32. 80 U.S. (13 Wall.) 679 (1871).

33. Id. at 682-83.

34. FORM OF GOVERNMENT OF THE PRESBYTERIAN CHURCH, at ch. $12, \S 5$, reprinted in Watson, 80 U.S. at $682-83$. 
Assembly found, as a matter of religious law, that the abolitionist contingent was the true representative of the Presbyterian Church and instituted a group of trustees to ward the property. The losers then brought their property claim into civil court, and the case was finally heard in the U.S. Supreme Court in 1871.

In Watson v. Jones, the Court held that "the rule of action which should govern the civil courts" in this class of cases was:

[W] henever the questions of discipline, or of faith, or ecclesiastical rule, custom, or law have been decided by the highest of these church judicatories to which the matter has been carried, the legal tribunals must accept such decisions as final, and as binding on them, in their application to the case before them. ${ }^{35}$

The Court held that this rule was "founded in a broad and sound view of the relations of church and state under our system of laws, and supported by a preponderating weight of judicial authority."36

The Court contrasted the American doctrine with the English rule, which held that civil courts were duty bound to inquire into theological doctrine and settle matters of religious law. ${ }^{37}$ The Court attributed this divergence from English law to the differing religious cultures. England's established church and the intimate authority that the government held over religion compelled a doctrine that would be obnoxious in the American atmosphere of limited government and religious liberty. ${ }^{38}$

The Watson doctrine thus recognizes a legal sovereignty for religious judicatories. That is to say, the doctrine recognizes the capacity of religious lawfinders to find law that will be ultimately and independently authoritative.

There have been some recent applications of Watson, ${ }^{39}$ many of which have allowed its common law reasoning to collapse into an assortment of

35. Watson, 80 U.S. at 727.

36. Id.

37. The English rule was developed mainly by Lord Eldon, the Lord Chancellor of England, in the early 19th century. See Craigdallie v. Aikman, 2 Bligh 529 (H.L. 1820) (appeal taken from Scot. Sess.) (dispute over ownership of religious meeting house); Attorney General v. Pearson, 3 Merivale 353 (Ch. 1817) (court not bound by religious law).

38. Watson, 80 U.S. at 727-29. Justice Miller's opinion is justly famous for the observation that, in America, "the law knows no heresy." Id. at 728.

39. See, e.g., Jones v. Wolf, 443 U.S. 595 (1979) (applying "neutral principles of law" in church property dispute did not violate First and Fourteenth Amendments); Maryland \& Va. Churches v. Sharpsburg Church, 396 U.S. 367 (1970) (church property dispute); Presbyterian Church v. Hull Church, 393 U.S. 440 (1969) (same). These cases introduced the notion of "neutral principles of law" into free exercise jurisprudence. They held that purely religious questions were beyond the ken of civil adjudicatory bodies, but that questions that could be translated into civil legal terms could be adjudicated by the state according to neutral principles of law. These cases undermined Watson by suggesting that the state's adjudicators are not bound by the findings of religious lawfinders, and foreshadowed Smith by forcing the state's terms upon religious law. See also NLRB v. Catholic Bishop, 440 U.S. 490 (1979) (NLRA not applied to church-operated schools); Serbian Orthodox Diocese v. Milivojevich, 426 U.S. 696 (1975) (church property dispute). 
"entanglement" tests ${ }^{40}$ commonly associated with Establishment Clause cases. ${ }^{41}$ It may be that such analysis obfuscates the real legal meaning of Watson. To recapture that meaning we must attend something of an archeological dig upon the principle itself.

\section{B. The American Common Law of Religious Lawfinders}

The common law method is the slow and gradual process of sorting things out. Such gradual movement has marked the development of the American common law regarding religious societies. In contrast to other fields of common law, such as contract or torts, however, the American common law regarding religious societies exhibits a distinctive wrinkle: American common lawyers did not simply pick up at the point where the British left off.

The flight from England was, in many significant respects, a flight from some English ideas about governance and law. In order to understand the American common law of religious lawfinders we should begin with some much more basic concerns that shaped the development of the nascent American state. ${ }^{42}$ First let us investigate the American reevaluation of the relationship between the state and religion. Then let us consider the common law's attempt to extend the state's legal recognition to religious societies; that is, to wrap up religious reality in the state's legal language and thus make it cognizable to the state. Only then should we examine the state's attempt to craft rules that would coordinate the peculiar lawfinding capacity of religious societies with the state's general task of governance.

\section{Coming to a Reality}

Much of the American common law concerning religious societies developed as a reaction to some features of English legal systems that had earned the disfavor of American lawyers and the ire of American revolutionaries. Let me distill two such features. The first, which I shall call the "omnicognizance" of the law, holds that there are no limits upon the capacity of the state's legal institutions to grasp, conceptualize, and evaluate any human action. A legal system that possesses omnicognizance can exhaustively translate any social phenomenon into the system's own legal language and thus speak authorita-

40. But cf. Kedroff v. Saint Nicholas Cathedral, 344 U.S. 94, 121 (1952) (Frankfurter, J., concurring) (dispute over statutory transfer of control of Russian Orthodox church away from Moscow); id. at 126 (Jackson, J., dissenting) (same).

41. The leading such case is Lemon v. Kurtzman, 403 U.S. 602 (1971) (disbursements to religiously run schools). The times, however, seem to augur well for a substantial revision of the Lemon analysis. See County of Allegheny v. ACLU, 492 U.S. 573 (1989) (menorahs and Nativity scenes).

42. This Note takes the perspective of the state by asking: "How did the state try to make sense of religion?" Of course, to complete the story of religious lawfinders one would have to investigate the matter from the point of view of the religious communities as they tried to make sense of the state. 
tively to that phenomenon. It follows that if there are no limits to a system's legal cognizance, there are no limits to that system's legal dominion. The second feature, which folds over the first, is the model of the solitary sovereign; that the Parliament (or the crown) is the single legal sovereign, the source of all law in the land. Under this model there is a unitary law and a unitary lawgiver; any other body with a semblance of legal authority actually borrows that authority from the solitary sovereign.

After breaking away from the mother jurisprudence and shaking off her bad habits by gradually disestablishing the established colonial churches, ${ }^{43}$ the American common lawyers of the middle nineteenth century finally received the opportunity they needed to sort out for themselves whether these two English legal principles (among others) were compatible with American social reality. A brief glimpse at a few early American cases treating religious societies will give us a sense of the legal conversation of the day.

In 1868 the Supreme Court of New Hampshire issued an injunction, sought by some members of a house of Unitarian worship, against the wardens of that house. The injunction ordered the wardens to prevent a man named Abbot, who held views somehow abrasive to the principles of Unitarianism, from preaching at the house of worship. The majority opinion in the case, Hale v. Everett, observed that the house of worship had been constructed and was owned by Unitarians for the purpose of propagating the Unitarian faith. ${ }^{44}$ The court determined that the views of the Reverend Mr. Abbot, as entered into evidence, were theologically inimical to the system of Unitarianism and therefore issued the injunction. ${ }^{45}$

The dissenting opinion in the case, written by Justice Doe, ${ }^{46}$ pointed out that the argument of the court follows only if the civil courts of New Hampshire were legally authorized to find and apply religious law; that is, if the legal cognizance of the state extended to religious law. Doe balked at such a characterization of the legal authority of New Hampshire courts.

This dispute echoes a debate that had been ringing through the corridors of American courthouses for a long time: Does American common law adopt the English maxim that "Christianity is a part of the law"? 47 "If Christianity were in any sense ... a part of the common law of New Hampshire," noted Justice Doe, "it would be the right and duty of this court to decide what Christianity is, and to enforce it as law ... by the whole power of the state

43. See, e.g., Baker v. Fales, 16 Mass. 492 (1820); Adams v. Howe, 14 Mass. 340 (1817); Gallego's Ex'rs v. Attorney General, 30 Va. (3 Leigh) 450 (1832).

44. 53 N.H. 9, 49-51 (1868).

45. Id. at 87,133 .

46. Id. at 133 (Doe, J., dissenting).

47. See, e.g., Vidal v. Girard's Ex'rs, 43 U.S. (2 How.) 127, 198-201 (1844); 1 THOMAS JEFFERSON, Jefrerson's WrTtings 360-67 (Paul L. Ford ed., 1904); Joseph Story, Christianity a Part of the Common Law, 9 AM. JURIST 346-48 (1833) (responding to Jefferson); THOMAS M. COOLEY, CONSTITUTIONAL LIMITATIONS WHICH REST UPON THE LEGISLATIVE POWER OF THE STATES OF THE AMERICAN UNION 588-90 (4th ed. 1878). 
placed in our hands for the purpose."48 But Doe declared that "Christianity ... is not ... any part of the common law." ${ }^{\text {"49 }} \mathrm{He}$ noted that the principles of Christianity are obtained by divine revelation while the common law is hewn from a specific legal culture through reason and experience. ${ }^{50}$ Moreover, the two systems differ in more than method. Justice Doe pointed out that the design of the common law affords it cognizance of only a certain limited set of misdeeds. He observed that the police may arrest an "orange-woman" who obstructs a public street with her wheelbarrow, but that the police may not arrest a "miser who has amassed a million" because she allowed a dear friend and benefactor to suffer and die in a workhouse. "Is this because legislators think the orange-woman's conduct worse than the miser's? Not at all. It is because the stopping up of the pathway is one of the evils against which it is the business of the public authorities to protect society; and heartlessness is not one of those evils." 51

Doe's rejection of omnicognizance has its roots in a thoughtful appraisal of the nature and structure of the state's legal power:

Every institution, art, and science is not ordained for the accomplishment of all other purposes of creation: some are assigned to one work, some to another: if each is equal to its office, it is sufficient. The common law is not designed to be either a civil agency of the church, or an ecclesiastical institution of the state. It does not claim either a divine or a human authority to propagate or patronize any system of theology, to enforce or interpret the divine law, or to control or regulate the relations between mankind and the supreme government of the universe. ${ }^{52}$

Far more than any discretionary doctrine of "judicial modesty," Justice Doe's position suggests that as a canon of constitutional construction, the authority of the state's legal institutions simply does not extend to some questions:

The true construction of the constitution is that which makes every parish theologically independent of the state, and leaves the pulpit of every parish in the control of the parish, free from the theological correction of secular tribunals. The constitution, like the common law ... [is not] a theological system. It is human law, reverently recognizing the inviolability of religion $\ldots .^{53}$

The second English principle, that of the solitary sovereign, also received some judicial attention in cases concerning religious societies. One court tried

\footnotetext{
48. Hale, 53 N.H. at 202 (Doe, J., dissenting).

49. Id.

50. Id.

51. Id. at 210-11 (quoting THOMAS B. MACAULAY, ESSAY ON CHURCH AND STATE (rev. ed. 1839)).

52. Id. at 210 .

53. Id. at 223-24; see also Chase v. Cheney, 58 Ill. 509 (1871).
} 
to import this English principle into American law. In the 1846 case of Smith v. Nelson, the Supreme Court of Vermont declared the power of the church in the instant dispute to be a "phantom" because it did not draw upon the solitary sovereign (in this case, the State of Vermont). ${ }^{54}$ The court went on to deny categorically the proposition that religious societies exercise any lawfinding power independent of the state: "The proceedings of . . . any ... ecclesiastical tribunal in this country ... are not to be held conclusive and absolute when they come in question in courts of law." "55 However, this view, as was pointed out by the New York Court of Appeals twenty-eight years later, was "in conflict with the general course of judicial decisions everywhere in this country." 56

The American common law had thus begun to voice its doubts about the adequacy of the old English notions of omnicognizance and the solitary sovereign as a satisfactory legal approach to the reality of religious societies in a new world of religious liberty. Let us now consider the common law's attempts to develop a more appropriate legal category.

\section{The Legal Naming of Religious Societies}

A brief look into a few traditional fields of common law will give us a sense of how American common lawyers began trying to make fresh legal sense of religion. One question, posed in the context of trust law, afforded an excellent opportunity for the state to attempt a definition of religious societies: How should a court administer a trust intended for the ongoing use of a religious society when that society substantially alters its form $^{57}$ or its doctrine? ${ }^{58}$ Again, American common lawyers approached this question very differently from their English counterparts. The English rule, enunciated by Lord Eldon in his famous opinion in Attorney General v. Pearson, ${ }^{59}$ stated that "if a fund, real or personal, be given in such a way that the purpose be clearly expressed to be that of maintaining a society of Protestant Dissenters ... it is then the duty of this Court to carry such a trust as that into execution, and to administer it according to the intent of the founders." ${ }^{60}$ The trust, by this rule, received a strict interpretation according to the intention of the founders. ${ }^{61}$ Thus, if a settlor found a trust for a particular religious society, and that society subse-

54. 18 Vt. 511,550 (1846).

55. Id. at 558 .

56. Connit v. Reformed Protestant Dutch Church, 54 N.Y. 551, 564 (1874).

57. See, e.g., McGinnis v. Watson, $41 \mathrm{~Pa} 9$ (1861) (Congregationalist church forms union with Presbyterian church).

58. See, e.g., Gonzalez v. Roman Catholic Archbishop of Manila, 280 U.S. 1 (1929) (Roman Catholic Church refines its canonical conception of "chaplaincy").

59. 3 Merivale 353 (Ch. 1817).

60. Id. at 409.

61. This rule is also exercised by Lord Eldon in Craigdallie v. Aikman, I Dow's Parl. Rep. 1, 16 (H.L. 1812-1813) (appeal taken from Scot.) (property dispute between two factions of church). 
quently underwent some substantial change in its theological principles, the court was obligated to divert the money of the trust.

It was this mechanical immediacy that troubled American common law courts and led them to reject the English rule. ${ }^{62}$ Such interpretive strictness implies that a religious society consists of a body of static doctrine; a change in the doctrine means the dissolution of that society and the formation of another. ${ }^{63}$ American common law rejected this thin theory of religious societies, noting that it fails to acknowledge the personality and the inevitability of change that characterize living phenomena. ${ }^{64}$

More of the nuance of the common law's appraisal of religion is evident in cases where parties requested that the state monitor the procedural regularity of the inner workings of religious bodies. In a series of cases, ${ }^{65}$ courts forged the principle that " $[t]$ he ordinary courts have no cognizance of the rules of a religious organization or other voluntary association, and cannot consider whether they have been rightly or wrongly applied." 66

The common law's cautious approach to religious bodies seems compelled by an instinct that the phenomenon of religion is beyond the legal cognizance of the state. This notion of the legal inscrutability of religion is especially clear in cases concerning incorporation.

Though the state was obliged to govern religious bodies, it found it difficult to bring those bodies within legal cognizance. The statutory device of incorpo-

62. See the rejection of Eldon's rule by the Pennsylvania Supreme Court in McGinnis v. Watson, 41 Pa. 9, 16 (1861). Similarly, Justice Brandeis, writing for the Supreme Court, rejected a strict interpretation of a trust in Gonzalez, 280 U.S. at 17. The contest between thick and thin legal characterizations of religious bodies was the fulcrum of the Court's judgment in Kedroff v. Saint Nicholas Cathedral, 344 U.S. 94 (1952). Significantly, the latest word from the Supreme Court hinted at a return to the strict view. See Jones v. Wolf, 443 U.S. 595, 604-05 (1979).

63. See Harold Laski, Notes on the Strict Interpretation of Ecclesiastical Trusts, 36 CAN. L. TIMES 190, 194-95 (1916).

64. See Gonzalez, 280 U.S. at 1; McGinnis, $41 \mathrm{~Pa}$. at 9. The common law history of the thicker legal theory of religious bodies as possessing juristic personalities is chronologized in Ponce v. Roman Catholic Church, 210 U.S. 296, 319-23 (1908) (recognizing legal personality of Roman Catholic Church); see also Laski, supra note 63, at 195-98. The idea of personality and legal incorporation is developed in ERNST KaNTOROWICZ, THE KING's Two Bodies: A STUdY IN MEdiaEval POlITICAL THEOLOGY (1957).

65. See, e.g., Watson v. Jones, 80 U.S. 679 (13 Wall.) (1871) (religious society determines own membership); Kuns v. Robertson, 154 Ill. 394 (1895) (secular courts have no authority to adjudicate questions of religious doctrine); Chase v. Cheney, 58 Ill. 509 (1871) (ecclesiastical courts have final say on offenses to church discipline); Ferraria v. Vasconcelles, 23 Ill. 403 (1860) (recognizing validity of Presbyterian rules of property ownership); Shannon v. Frost, $42 \mathrm{Ky.} 253$ (3 B. Mon.) (1842) (church is sole judge of excommunication); Connitt v. Reformed Protestant Dutch Church, 54 N.Y. 551 (1874) (secular court to accord great weight to religious tribunal's determination of its own jurisdiction); Walker $v$. Wainwright, 16 Barb. 486 (N.Y. App. Div. 1853) (secular court to recognize jurisdiction of ecclesiastical tribunal); Harmon v. Dreher, 1 S.C. Eq. (1 Speers Eq.) 87 (Ch. 1843) (secular court will not review synod's expulsion of member).

66. Fussel v. Hail, 233 Ill. 73, 77 (1908). But cf. Gray v. Christian Soc'y, 137 Mass. 329 (1884) (Holmes, J.) (state may require church to follow its own bylaws). The scope of Gray was refined by Cohen v. Silver, 277 Mass. 230 (1931) (lack of notice or hearing does not require court's overruling of church decision). Judicial review of religious procedure seems lately to be returning to favor. See Babcock v. Baptist Theological Seminary, 554 So. 2d 90 (La. Ct. App. 1989) (reviewing seminary procedure for dismissal of student), cert. denied, 558 So. 2d 607 (La. 1990), cert. denied, 111 S. Ct. 214 (1990). 
ration was a step toward solving this problem of jurisdiction. Because a corporation is a legal artifice and purely a creature of the state it falls, by definition, within the state's legal cognizance. Therefore, the state may govern, in the sense of holding a legal conversation with, the incorporation of a religious body without having to speak to the religious body itself.

As courts honed the device of incorporation they underscored the notion of the legal inscrutability of religious bodies. In Hardin v. Baptist Church, Justice Thomas Cooley of the Michigan Supreme Court emphasized the ontological distinction between the religious body and the legal corporation. "The church," noted Justice Cooley, "is not incorporated," for incorporation describes not the process of converting a religious body into a legally cognizable entity, but describes rather the process of shaping a new creature from the legal clay and breathing life into it afresh. "The church is not incorporated and has nothing whatever to do with the temporalities," ${ }^{67}$ Cooley continued, "[o]n the other hand, the corporation has nothing to do with the church except as it provides for the church wants . . . And as to spiritual capacity, the corporation has none; it is given capacity in respect to temporalities only."

The New York Court of Appeals in Baxter v. McDonnell demonstrated the legal relevance of the distinction between church and corporation by dismissing a complaint in which the pleader had named the "Holy Roman Catholic Church" as the offending party:

If, wherever the word "church" appears . . . a mere abstraction had been used, as, for the sake of illustration the letter "X," the complaint would then allege that by virtue of the rules and regulations of " $X$ " the defendant assumed certain obligations and the plaintiff became entitled to certain rights, yet no one would seriously contend that such allegations constituted a cause of action. ${ }^{69}$

The church is thus a legal "X," an unknown quantity that confounds the equation. As described by the Supreme Court of Kentucky, "[t]he judicial eye of the civil authority of this land of religious liberty, cannot penetrate the veil of the Church, nor can the arm of this Court either rend or touch that veil," for the church, according to the Supreme Court of Pennsylvania, "is to be a law unto itself, ... to have its law within itself."

67. Hardin v. Baptist Church, 51 Mich. 137, 138-39 (1883) (corporation cannot be sued for church's actions).

68. Id.

69. Baxter v. McDonnell, 155 N.Y. $83,95-96$ (1898).

70. Shannon v. Frost, 42 Ky. (3 B. Mon.) 253, 259 (1842) (declining to review claims of excommunicated members).

71. McGinnis v. Watson, $41 \mathrm{~Pa} .9,14$ (1861). 


\section{Crafting a Rule of Coordination}

Religious bodies, while legally inscrutable to the state, are not legally impotent. Religious lawfinders expound religious law, which binds the actions of some citizens in ways directly affecting the state's interests. A secular legal system is thus challenged to fit the operation of religious law within the state's general task of governance.

The common law doctrine enunciated in Watson $v$. Jones provides a rule of coordination. In essence, the Watson doctrine concerns the finality of judgments: when religious lawfinders have ruled on religious law, "the [state's] legal tribunals must accept such decisions as final, and as binding on them, in their application to the case before them." 72 By recognizing the holdings of religious lawfinders as final and binding upon civil legal institutions, the state recognizes the legal sovereignty of religious lawfinders and implies that they possess a legal authority independent of the state.

We have already seen that what I am calling the "Watson doctrine" far antedates the Watson decision and actually roots quite deeply in American legal culture. The cases that establish this rule of finality echo the common law's general discomfort with the notions of omnicognizance and the solitary sovereign. In these cases, the courts express an awareness of their own inherent limitations as lawfinding institutions and recede in the presence of other authoritative lawfinders. ${ }^{73}$ In German Reformed Church v. Seibert, ${ }^{74}$ for example, a Pennsylvania court placed religious lawfinders on precisely the same sovereign footing as the state's legal institutions: "The decisions of ecclesiastical courts, like every other judicial tribunal, are final; as they are the best judges of what constitutes an offense against the word of God and the discipline of the church."75 Perhaps more vivid is the Supreme Court of Indiana's holding in White Lick Quarterly Meeting of Friends $v$. White Lick Quarterly Meeting of Friends: "Where a civil right depends upon some matter pertaining to ecclesiastical affairs, the civil tribunal tries the civil right, and nothing more, taking the ecclesiastical decisions, out of which the civil right has arisen, as it finds them, and accepting those decisions as matters adjudicated by another jurisdiction." $" 76$

72. Watson v. Jones, 80 U.S. (13 Wall.) 679,727 (1871).

73. See, e.g., Watson v. Avery, $65 \mathrm{Ky}$. (2 Bush) (1867) (court can rule only on church lawfinder's jurisdiction); Shannon v. Frost, 42 Ky. (3 B. Mon.) 253 (1842); Missouri ex rel. Watson v. Farris, 45 Mo. 183 (1869); Wehmer v. Fokenga, 57 Neb. 510 (1899); Pounder v. Ashe, 44 Neb. 672 (1895): Den v. Bolton, 12 N.J. Eq. 206 (1831); Harmon v. Dreher, 1 S.C. Eq. (Speers Eq.) 87 (Ch. 1843). But cf. Watson v. Garvin, 54 Mo. 353 (1873) (disapproving of Watson v. Jones), overruled by Hayes v. Manning, 263 Mo. 1 (1914).

74. $3 \mathrm{~Pa}, 282$ (1846).

75. Id. at 291 .

76. 89 Ind. 136, 151 (1883) (emphasis added). 


\section{Civil Courts and Religious LaW}

We are now in a position to lift our eyes from the springs and sprockets of the Watson doctrine and take in the broader view. Our examination of this civil doctrine concerning religious lawfinders, when placed in its common law context, may indicate some things of value about America's legal culture.

\section{A. The Legal Sovereignty of Religious Communities}

The findings that constitute what I am calling the Watson doctrine suggest that the civil law understands religious lawfinders as the legal institutions of sovereign religious communities. When the court in White Lick, for example, described the religious lawfinder as an institutional actor of "another jurisdiction," it acknowledged that the parties to the case were subject to another legislative jurisdiction and were therefore bound by the laws of another sovereign. ${ }^{77}$ Similarly, the Presbyterian claimants in Watson v. Jones, who brought their civil claim before the U.S. Supreme Court after their religious claim had already been adjudicated by the lawfinder of the Presbyterian Church, were treated just as though they were citizens of Mexico petitioning an American court. The Watson doctrine might thus describe a "choice of law" rule that civil courts have adopted to tell them which set of rules to apply when adjudicating a dispute involving more than one jurisdiction. ${ }^{78}$

\section{B. The Religious Question Doctrine}

The Watson doctrine also enhances our awareness of how the common law understands the internal order and the limits of the state's own lawfinding institutions. Perhaps the model of a "religious question doctrine," analogous to one version of the political question doctrine, will help to illuminate the civil courts' habit of refraining from inquiry into matters of religious law. ${ }^{79}$

The "religious question" analog would operate both on the level of positive law and on the level of natural law. Positive law refers to that law which is posited by some institutional actor at some specific time. ${ }^{80}$ An inquiry gov-

77. Id.

78. See Perry Dane, Note, Religious Exemptions Under the Free Exercise Clause: A Model of Competing Authorities, 90 YALE L.J. 350, 365-76 (1980).

79. For discussions of the political question doctrine, see generally ALEXANDER BICKEL, THE LEAST DANGEROUS BRANCH 183-98 (2d ed. 1986): HERRERT WECHSLER, PRINCIPLES, POLITICS, AND FUNDAMENTAL LAW 11-14 (1961); Alexander Bickel, The Supreme Court, 1960 Term-Forward: The Passive Virtues, 75 HARV. L. REV, 40, 74-79 (1961); Maurice Finkelstein, Further Notes on Judicial Self-Limitation. 39 HARV. L. REV. 221 (1925); Maurice Finkelstein, Judicial Self-Limitation, 37 HARV. L. REV. 338 (1924); Louis Henkin, Is There a "Political Question" Doctrine?. 85 YALE L.J. 597 (1976).

80. Professor Robert Cover described positive law as the "arbitrary act of an authority." See Lectures by Cover on American Legal History (1985) (tapes on file with Yale Law School Library). "Arbitrary" is to be juxtaposed with "necessary." The institutional actor posits one law rather than another as an expression of will, rather than as required by the nature of the thing to be regulated. 
erned by the logic of positive law would include simply the verification of the authority of the positor and the clarification of the meaning of the posited. Natural law, on the other hand, while not denying that the theory of positive law accurately describes some law, contends that in some instances law is authoritative because it accurately affirms the structure of that phenomenon we are seeking to govern, that such law is "found" through the scrutiny of that phenomenon rather than "made" by any particular institutional actor, and that the authority of such law persists despite the attempts of any institutional actor to posit the contrary. An inquiry governed by the logic of natural law would require using human reason to discern the law of the thing in its nature.

Underpinning the distinction between positive and natural law is the further distinction between "positive" and "affirmative" theories of authority. A law has positive authority when the positor of that law has authority; on the other hand, a law has affirmative authority when it accurately affirms the nature of some extralegal reality.

The positive lawyer's argument for a religious question doctrine would direct our attention to a particular text, written by an authoritative positor, that removes religious questions from the jurisdiction of the state. We find that text in the Establishment Clause of the First Amendment, which arguably makes the state into an "a-religious" actor, thus putting religious questions beyond the jurisdiction of the state.

The argument from natural law, on the other hand, would invite us to discern the nature and limitations of the state's lawfinding institutions. The natural lawyer would begin by noting that legal conversations about political questions are relevant for the purposes of this Note, not because they define what a political question is, but rather because they cause us to think about what a judicial question is not. The specific sort of political question analysis I have in mind was stated by Justice Brennan, who wrote for the Court in Baker v. Carr, and noted that a question is not judicial when there is a "lack of judicially discoverable and manageable standards for resolving it." 81 Justice Frankfurter, in his dissenting opinion in that case, echoed this formulation by noting that a question is not judicial when "there exists no standard ascertainable by settled judicial experience or process by reference to which ... the parties can be judged." 82

One reading of this criterion is that the judicial power does not extend to those questions that cannot be scrutinized by using the judicial method. The judicial method, we learn from Alexander Hamilton, ${ }^{83}$ is characterized by judgment, rather than by force or will; and judgment is a process of intellectual discernment. When the question presented is beyond the legal cognizance of a court, it is beyond its legitimate judicial power of intellectual discernment.

8I. 369 U.S. 186, 217 (1962).

82. $l d$, at 282 (Frankfurter, J., dissenting).

83. THE FEDERALIST No. 78, at 465 (Alexander Hamilton) (Clinton Rossiter ed., 1961). 
Should the court exercise power over such a question, the power exercised would be force or will; it would not be legitimate judicial power. ${ }^{84}$

Moreover, we would say that a question is beyond a court's legitimate power of intellectual discernment when the substance of that question is beyond the competence of the court. For example, an adjudicatory body designed and empowered to hear only cases in admiralty would be ill-equipped to decide a products liability case concerning the manufacture of automobiles. We would say that such a case is beyond that court's competence, and thus beyond its capacity for judgment.

A similar analysis would operate in a "religious question" doctrine. Civil courts are simply inappropriately structured to handle religious questions, and this inappropriateness runs to the scope of their legitimate authority. Should the state's court attempt to decide a question of religious law, it would transgress its legitimate authority by operating beyond its design. As the Watson doctrine suggests, matters of religious law are beyond the capacity of judgment that the state's courts can exercise.

\section{Legal Pluralism}

A final important lesson of the American common law of religious lawfinders is that pluralism among institutional lawfinders forms a real part of American legal culture. If the experience of the common law is any guide, a multiplicity of lawfinders works coordinately with a multiplicity of sovereign lawgivers, with the state and various religious communities serving as just two representatives of a variety of lawgivers. ${ }^{85}$ Any adequate description of America's legal culture must provide an account of this pluralism. Perhaps more importantly, any legal reform that the state undertakes must be substantially informed by this fact of pluralism, for the law makes itself ridiculous when it refuses to recognize reality.

\section{REVISITING FREE EXERCISE DOCTRINE}

\section{A. Sovereignty and Smith}

I will now turn to the relationship between the common law doctrine recognizing the sovereignty of religious lawfinders and contemporary free exercise doctrine. What does Watson have to say to Smith?

At first glance, it seems that an interlocutor would have an easy time distinguishing the two cases. On the facts, our interlocutor would observe that Smith, unlike the cases culminating in Watson, contained no specific question

84. See generally Lon Fuller, The Forms and Limits of Adjudication, 92 HARV. L. REV. 353 (1978).

85. See generally Cover, supra note 31 , at 4. 
of religious law that had been settled by an institutional lawfinder. On the law, our interlocutor might point out that the Watson doctrine was crafted for times of accommodation, when the state can afford to consider the value of religious autonomy as part of its political calculus; Smith, on the other hand, is designed for times of conflict between the norms of a religious community and the perceived survival of the state. When drums speak out in matters of gravity, real or imagined, the state prevails unless it chooses to relent.

Moreover, our interlocutor might contend that instances of what I have called "religious lawfinding" are nothing more than examples of "private ordering" where, beneath the protective wing of the ultimately sovereign state, individuals gather in association and agree to bind themselves to the rulings of the judicatories they create. ${ }^{86}$ The "private ordering" model denies that religious communities are like "another jurisdiction," 87 and suggests instead that religious communities more closely resemble organizations such as the Elks Club. As a private organization, the Elks Club could sustain the standard weak claims against government intrusion, but it could not seriously suggest that it should be accorded a presumption of legal sovereignty.

Yet, these attempts to distinguish Smith from Watson overlook the plain fact of the common law sovereignty of religious lawfinders. Watson, we have seen, simply echoes the resolve of the American legal tradition in proclaiming religious communities sovereign and their laws inscrutable. ${ }^{88}$ On the facts, Smith concerned a party who was governed by a norm generated by a religious community, so it does not escape the analogical pull of the Watson doctrine. On the law, the model of sovereignty implicit in Smith rejects Watson, rather than merely distinguishing it. Such a rejection merits candor and careful study.

86. See The Bremen v. Zapata Off-Shore Co., 407 U.S. 1 (1972) (forum selection clause of contract binds, even where clause has the effect of ousting jurisdiction of American court); see also Rodriguez de Quijas v. Shearson/American Express, 490 U.S. 477 (1989) (embracing encouragement of arbitration as adjudicative goal in securities cases); Grayson-Robinson Stores v. Iris Constr. Corp, I68 N.E.2d 377 (N.Y. 1960) (discussing relationship between arbitration and adjudication); Matter of Staklinski (Pyramid Elec. Co.), 6 N.Y.2d 159 (1959) (same).

87. White Lick Quarterly Meeting of Friends v. White Lick Quarterly Meeting of Friends, 89 Ind. 136, 151 (1883).

88. This is not to say that the "private ordering" model is always irrelevant to the adjudication of disputes of religious communities. There are times when a religious community, for the purposes of the dispute, behaves just like a private organization, and a civil court may thus adjudicate the dispute without having to reach questions of religious law. For example, in Smith v. Swormstedt, 57 U.S. 288 (16 How.) (1850), a Methodist community had divided into two sects, and the question before the Court was simply how to divide the jointly held property. That case, unlike Watson v. Jones, 80 U.S. (13 Wall.) 679 (1871), asked the Court to decide a question of property law ("how to divide jointly held property?") and not religious law ("which of two sects has been loyal to the church?"). The "private ordering" model is generally an inaccurate description of religious communities, however, because that model misunderstands the source of authority in religious law. The quintessential scheme of private ordering is the contract. In contract the source of the law resides in the parties to the contract who have agreed to bind themselves by their word. In religious systems, on the other hand, the source of the law resides well beyond the individual who gives assent; for the believer, the source of the law resides in God. 
The model of sovereignty at work in Smith portrays the state as the solitary sovereign. In times of accommodation the state's sovereignty lies dormant, but in times of conflict the sovereign awakens and indelicately asserts its order.

Again, the dimensions of the Smith model of legal sovereignty sharpen as we consider presumption. Every case in the Watson line concedes that the state may regulate religiously motivated actions if it can demonstrate that those actions transgress "the bounds of social order and morality." 89 But Smith, by shifting presumption, profoundly alters this arrangement. Smith establishes that the state can regulate religious liberty without having to demonstrate a compelling state interest in the particular case. This would be analogous to an American court deciding to overrule the decision of a Mexican court regarding a dispute implicating Mexican parties acting according to Mexican law, and then enforcing this American judgment against the Mexican litigants. Such action would constitute an intrusion into Mexico's jurisdiction, and a denial of Mexico's legal sovereignty.

\section{B. Common Law Conceptions and Constitutional Interpretation}

To what extent do common law notions of religious legal sovereignty bind the constitutional adjudication of free exercise cases? It is too late in the day for us to argue that the common law provides essential interpretive context for the U.S. Constitution. There was a time, however, when no less a legal luminary than Justice Joseph Story defended this position. "[I]t can hardly be doubted," wrote Story in an 1813 circuit court opinion that was subsequently reversed, "that the constitution and laws of the United States are predicated upon the existence of the common law." "Story went on to note that many terms in the constitutional document are "inexplicable without reference to the common law" and that "[t]he existence ... of the common law is not only supposed by the constitution, but is appealed to for the construction and interpretation of its powers." 91

There are at least two reasons why Story's vision today provides an inadequate matrix for constitutional interpretation. First, the claim that one must interpret the Constitution in light of the common law overlooks the historical fact that the American legal revolution, perhaps reified in the text of the Constitution, was a political reaction against the fundamental common law idea that law could have its source in something other than the "people," the expression of the popular will. ${ }^{92}$

89. McGinnis v. Watson, 41 Pa. 9, 14 (1861).

90. United States v. Coolidge, 25 F. Cas. 619, 619 (C.C.D. Mass. 1813), rev'd, 14 U.S. 415 (1816).

91. Id.

92. See, e.g., Akhil R. Amar, Philadelphia Revisited: Amending the Constitution Outside Article V, 55 U. CHI. L. REV. 1043 (1988) (proceeding from a notion of popular sovereignty). 
The second reason to reject Story's claim has to do with the nature of the thing to be interpreted. As we have seen, the common law method involves the judicial scrutiny of social phenomena, such as religious organizations, with an eye toward discerning the immanent rules by which those phenomena are governed. Compare this with the act of constitutional interpretation that, at least in those cultures containing a written constitution, ${ }^{93}$ focuses on a particular text. Here the thing to be interpreted is legal rather than social; words on a page rather than bodies out there in the world. When it is words on a page that occupy our attention, the common law method properly defers to methods we call "statutory construction."

But if we cannot accept Story's vision wholesale we can, at least, learn a great deal from it. For legal phenomena frequently (but not always) find their ultimate referent in social phenomena. In the instant case, for example, the legal guarantee of the "free exercise of religion" necessarily proceeds from the antecedent social reality of religion. Thus, the ruminations and conclusions of the common law, as well as the indications of tradition, regarding the nature of religious bodies are of great value as an interpretive device for those words of the Constitution that pertain to religion. An interpretation of those words that directly defies the findings of the common law and the surrounding social traditions should incite some suspicion.

In response, however, an interlocutor may observe that much of recent legal history describes the deliberate erosion of the common law. The enactment of worker's compensation statutes, for example, required employers to pay for injuries their employees sustained while on the job, and the enactment of married women statutes granted wives the legal capacity they needed to husband their own affairs. Both of these legal improvements overthrew common law regimes. The common law was fashioned in coarser times, and so embodies many values we, as a society, no longer hold. Our interlocutor might note that the common law of, for example, married women simply misapprehended reality when it concluded that married women were needful of some legal incapacity. Mistakes of law fall away with the sharpening of our legal sensibilities. Just so, concludes our interlocutor, perhaps the time has come for us to discard our common law of religious communities.

Thus, the final question of this Note must be left open for the reader: Does the American common law of religious societies misapprehend reality? The artifice of the law must be subordinate to the reality from which it draws its strength and which it seeks to govern. The American common law came to the reality of the religious community and found that it was sovereign. So the common law planted legal devices that would respect this sovereignty and learn to work with it. Now these devices are being uprooted, and it falls upon us to

93. Constitutional cultures without a written constitutional document, such as that of Israel, provide a fascinating point of reference. 
[Vol. 101: 211

look and see whether this legal development corresponds with the reality of religious sovereignty. For it remains an inspiring curiosity of our legal culture that Smith, even while positing the new law of free exercise, might itself be, in some structural sense, unlawful. 